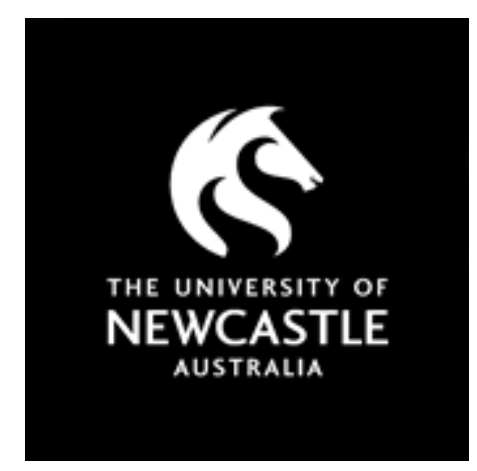

NOVA

University of Newcastle Research Online

nova.newcastle.edu.au

Lovat, Terence J, 'Bonhoeffer: interfaith theologian and practical mystic", Pacifica:

Australasian Theological Studies Vol. 25, Issue 2, p. 176-188 (2012)

Available from: http://dx.doi.org/10.1177/1030570X1202500206

Accessed from: http://hdl.handle.net/1959.13/1294196 


\title{
BONHOEFFER: INTERFAITH THEOLOGIAN AND PRACTICAL MYSTIC
}

\author{
(C) Terence J. Lovat
}

Referencing Details: Lovat, T. (2012 submitted for special issue). Bonhoeffer: Interfaith theologian and practical mystic. Pacifica: Australasian Theological Studies, 24

\section{Introduction}

Dietrich Bonhoeffer proffered that God would be Lord of the World but had been reduced to being a mere object of religion(s), the veritable local branch manager within the contested world of religions. The implication of his critique was that faith is not well served by institutional religious forms that tend to fashion conceptions of God to serve their own institutional purposes and, least of all when pitted against each other. For someone whose start in life was characterized by a traditional Lutheran Christian upbringing and who chose Lutheran ministry over many other professional pathways, such a broad interfaith assertion denoted a marked growth in Bonhoeffer's perceptions about God, his relationship to his church and indeed to the world more generally. These changed beliefs were impelled by circumstances that shook his earlier faith to its core, forcing him to reach beyond the narrow confessionalism of Lutheran Christianity to search for faith in other faiths - and even nonfaith - and, this article will contend, to achieve thereby some of the essential character of the mystic. The result of the search was heralded in his famous epithet 'religionless Christianity'. This chapter will sift the evidence that justifies Bonhoeffer being rightly regarded as laying foundations for interfaith theology and as a mystic, in his case a practical mystic as defined in antiquity.

\section{The Context and Spiritual Challenge: Religionless Christianity}

In the Nazi prison for his actions against Hitler, Bonhoeffer (1998) struggled to answer the question 'Who is Christ for us today?' Ancillary questions in effect included: Who is Christ for a church that had surrendered its integrity in the face of the vile, un-Christian Third Reich? How could this church ever hold its head high again? What did it mean to be Christian anymore? Who is Christ for a 'World Come of Age'?

Bonhoeffer posited the notion of 'religionless Christianity' (Bonhoeffer, 1998; Wustenberg, 1998; Pugh, 2008) as the answer to the above questions. The phrase connoted a way of conceiving of an essential Christianity that might credibly survive the times in which he was 
living, that could find meaningful dialogue between Christianity in its institutional form and that much broader world of authentic religious and non-religious commitment to truth and justice that he came progressively to see as the true work of God in the world, a work that super-ordinated his own Lutheran Christianity, Christianity as a whole and, indeed, religiousness itself. The common understanding that would bind these authentic forces in coalescence was what he described as the 'arcane discipline', connoting a deeply personal commitment to strive for the good of others that was consistent with the essence of the Christian gospel but neither exclusive to it nor the factual commitment of many (possibly most) who described themselves as Christian. Least of all was it the preserve of any denomination within Christianity. It represented conformity between one’s understanding, one's dispositions and one's actions that in fact could be found among Christians of many denominations, as well as among other religious and even non-religious people. It was arcane in the sense that it was essentially a private commitment devoid of the cosmetics of piety, whether among the religious or non-religious, and it was a discipline in that it connoted authenticity in contrast with shallow piety. In Bonhoeffer's terms, the sign of its authenticity would not be in the 'cheap grace' of religiousness but in the costly grace of conforming one's life and actions to serving the betterment of the human race, a commitment that coincided with the essential charter of Christianity. Cheap grace was what Bonhoeffer (1960) defined as:

... grace without discipleship, grace without the cross, grace without Jesus Christ, living and incarnate. (p. 30)

In this religionless Christianity, Bonhoeffer provided a formula for interfaith religious attenuation, a Christian spirituality that could survive only through foregoing the certainties that obtain from institutional adherence and replacing them with attenuation to the inspirational source to be found behind all religious expressions - and even non-religious expressions - namely, the God who would be Lord of the World, for Bonhoeffer most perfectly represented in the person of Jesus. In other words, Bonhoeffer brought forward an interfaith (and faith to non-faith) engagement as being central to the struggle for these answers, and ultimately to his mystical growth. For one brought up in the safe and secure environment of a Protestant orthodoxy that had taught him there could be no salvation beyond faith in the God revealed in the Christian Bible, these engagements would be crucial to his developing understanding of authentic spirituality and his character as a practical mystic. 


\section{Interfaith Engagement}

Bethge (1970) offers testimony that Bonhoeffer's interest in India and its spiritualities was an abiding and tantalizing passion and that he had a keen sense that Christianity had originally come from the East and that it was only through the East that it could ultimately be understood. Bethge (1970) quotes him as saying of Indian spiritualities: "Sometimes, it even seems to me that there's more Christianity in them than in the whole of the German state church.” (p. 330). The comment seems symptomatic of the profound change taking place in the mind and theology of a once ardent follower of Lutheran salvific exclusivity. In Mahatma Gandhi and the Indian based but essentially interfaith spirituality he saw implicit in him, Bonhoeffer came to see that other faiths could actually mirror Christianity as he understood it, not only providing an alternative pathway but indeed a better pathway for a Christianity quickly losing itself under the heel of the German state. He also learned from Gandhi that there could be no authentic faith without commitment to action that accorded with that faith. This was a further break with the 'justification by faith alone' theology which had constituted Bonhoeffer's formation. Gandhi's greatness was not only in the 'non-violent' action that he believed consistent with the Hindu and Jain theologies that had formed him and that became such a profound challenge to the British establishment, but also in his challenge to the pious members of India's various religions that one could not do God's work merely by having the right sentiments. The person of faith had to enact those sentiments, including putting right the wrongs that one confronted. The fact that Gandhi was prepared to shock both Hindus and Muslims with his explicit embodying of the religion of the Jains further inspired Bonhoeffer that true faith would always put benevolent action before denominational attachment (Lovat, 2006).

Bonhoeffer's dialogue with Gandhi and the religions of India was at a distance and one that never developed as he would have liked. He had written to Gandhi asking to come and stay in his Ashram and, according to Bethge, to actually learn how the Sermon on the Mount could take effect against a hostile enemy, an example of the mirroring effect of which Bonhoeffer spoke. In other words, Christians could learn much about Christianity by seeing its practical effects being enacted in non-Christian contexts. The war and imprisonment made the trip impossible so Bonhoeffer's engagement with Indian spiritualities remained truncated. Not so with Bonhoeffer’s dialogue with Judaism. 
Regarding his interfaith engagement with Judaism, Bonhoeffer struggled to maintain loyalty to the Lutheran theology of his formation, granted what he was quickly coming to understand about matters of faith. Like most of the reformation movements, Lutheranism had relied on Augustinian theology to justify its movement away from Rome and assert the centrality of the Bible, and one's faith in its message, as the sole means of salvation. Together with biblical translations into the vernacular which brought before the reader the clarity of the role played by the 'Jews' in the death of Jesus, renewed focus on Augustine also brought with it a reinvigorated focus on his damnation of the Jews for their “... abandonment of the God whom they had been the first of humans to recognize.” (Chazan, 2004, p. 61).

While a more sensitive reading of Augustine might have also uncovered his belief that the Jews should not be persecuted like other unbelievers because of the role they had played in preparing for Christ's coming, nonetheless, his use of the colourful term 'Christ-killers' as pertaining to the Jews did nothing to ameliorate the rising anti-Semitism of post Reformation Europe. In this escalating anti-Semitism, the earlier efforts of Aquinas to appeal to Jewish scholarship and mysticism itself to counter the views of Augustine and the Fathers were wiped away (Hood, 1995). The key reformers, Calvin, Zwingli, Knox, Cranmer and Luther all returned to the Augustinian theme of 'no salvation outside the church', with Jews routinely condemned as a failed people who must come to Christ to be saved. Most tellingly in the context of Bonhoeffer's formation, Luther had used one of his later works, On the Jews and their Lies' (Michael, 2006) to berate the Jews in arguably the harshest manner in all of the sad annals of Christian anti-Semitism. Heinrich Himmler, Hitler's Chief of the Gestapo and architect of the Jewish death camps, would go on to cite Luther freely in justifying the Third Reich's policies on the Jews. It was Luther's Christianity to which Bonhoeffer had been attracted and Luther himself with whom he identified as the model Christian, albeit for reasons far more noble than Luther's unmistakable anti-Semitism. Although there is no evidence of such blatant anti-Semitism in Bonhoeffer, one can point to earlier more typical Lutheran sentiments about the obsolescence of Judaism and also the (un)celebrated case whereby Bonhoeffer refused on religious grounds to take the funeral service of his twin sister's Jewish father-in law, an action he came to regret deeply later on (Moses, 2009).

Regardless of these earlier influences and sentiments, Bethge (1970) assures us that Bonhoeffer's final position on Judaism was not only one of profound compassion but of deep respect as well. Rasmussen (2005) agrees with Bethge that Bonhoeffer's primary motivation 
for engaging in resistance to Hitler related to his abhorrence at the treatment of the Jews. Furthermore, Fackenheim (1977), speaking from a Jewish perspective, described Bonhoeffer as the 'great saint' who, if he had lived, would likely have been one of the greatest Christian friends that Judaism would have, a view endorsed by Haberman (1994). Fackenheim (1982) also endorses Bethge's view that Bonhoeffer was one who had made possible a postHolocaust Christian theology.

It seems that Bonhoeffer's prison stance was impelled largely by witnessing the horrors of the 'final solution' as it became evident to him, and, in related fashion, as well as by the belief that one could not continue to proclaim Christianity if one did not take a position against these atrocities. The Jewish question was at sufficiently close quarters, including in his own family, for him to know of the suffering, the bravery and the faith of many Jews and, at the same time, the faithlessness of many pious Christians, including in Christian leadership, who knew about the travesties being inflicted on their fellow human beings but, in spite of their claims to be acting in Christ's name, in fact enacted nothing. These experiences became the focus of much soul-searching in prison as he strived to ponder on the meaning of faith and religiousness in the context of church-state complicity over the wicked goals and iniquitous practices of the Third Reich. Moreover, the views of Fackenheim $(1977,1982)$ and Haberman (1994) suggest that much of his prison theology is at least partly explained by a softening of the typical Lutheran spurning of Judaism and being replaced by a growing understanding of the deep interconnections between Judaism and Christianity, historically and theologically. Pangritz (1997, 1997a) endorses the view that, around the Jewish question, Bonhoeffer's prison theology was in sharp conflict with his own tradition and earlier thought.

The reformers' views of the other Abrahamic faith, Islam, were of course no better than towards Judaism. Fairly predictably, Calvin had described Muhammad as a false prophet and declared that Muslims would have to convert to Christianity to be saved. Cranmer meantime described Muslims as being of the devil, much like papists, while Luther referred to them as God's scourge. We have little evidence of Bonhoeffer's attitude to Muslims although it could be assumed that Bethge's reference to his fascination with the religions of India must have included some attention being given to Islam and, if so, there is no hint of the reformers' castigation to be found. Perhaps of greater interest is that works that have set out to address the issue of Islam and its relations with its sibling Abrahamic religions (cf. Goddard, 1995; 
Jacobs, 2009) have commonly made reference to Bonhoeffer's perspective as one that can be utilized in the interfaith quest to re-establish respect and dialogue. In similar fashion, works that are premised on the need for renewed forms of interfaith dialogue generally (cf. Alston \& Welker, 2003; Pugh, 2008) tend to refer to Bonhoeffer’s theology as being helpful in this regard. It seems that, just as Fackenheim (1982) identified Bonhoeffer as one whose work offered the potential for a post-Holocaust theology, so this work has potential for a postWorld Come of Age theology, a world in which interfaith theological dialogue is an imperative. Just as John Hick (1973, 1980, 1988, 1995), from a Christian stance, and Mohamed Talbi (1995, 2002; Talbi \& Jarczyk, 2002; al-Daddak, 2012), from a Muslim perspective, can be referred to as architects of twenty-first century interfaith theology, so can Bonhoeffer be numbered in that company (Lovat, 2010). In Bonhoeffer's 'World Come of Age', 'religionless Christianity' implied an arcane discipline that must include shedding the trappings of religious legalism, including those prejudices against other ways in which humankind expresses faith in the God who can no longer be a mere object of religion(s) but must truly be seen as Lord of the World (cf. Metaxas, 2010; Marty, 2011).

In a sense, the zenith of Bonhoeffer's (1998) steady movement from salvation by faith alone (meaning Christian, ideally Lutheran faith) to consideration and finally acceptance of salvation beyond Christianity is seen in his exploration of 'non-religious interpretation', a 'secular theology' for a world come of age (Hamilton, 1962). As with all of Bonhoeffer's prison theology, this one was built on his personal experiences of fraternity with the 'unfaithed', with those with whom he found himself sharing commitment and the conditions of prison but, unlike him, were not at all motivated by a faith position. Their sole motivation was an earthy integrity and a profound commitment to their fellow human beings. Bonhoeffer could not help but contrast these 'non-faithed', sometimes even self-professed 'atheists' and 'agnostics', with so many of his erstwhile 'enfaithed' colleagues whom he saw cowering behind the protective walls of the church. In this context, his earlier inspirational thoughts, whether from Barth's (1994) reliance on the revelation to be found in the Bible or from Von Harnack’s (Rumscheidt, 1991) search for the historical Jesus, became starkly narrow and incapable of addressing adequately the far wider spirituality that was now guiding Bonhoeffer's thought.

At this point, Bonhoeffer had not only moved well beyond the narrow bounds of Lutheran Christianity but the more specific theologies of his academic training as well. He had been 
changed by his magnified experience of religiousness (and non-religiousness) and became increasingly and painfully aware that he could never go back to the safety of his earlier much simpler beliefs and theologies about religiousness, salvation and the church's role in assuring them. Bonhoeffer had to find a way of capturing intellectually these huger, more spiritually enriched thoughts about a God who is beyond faith as normally defined, a theology suited to a world come of age. At this point, the central question posed for this world come of age, 'Who is Christ for us today?', is responded to with a 'non-religious interpretation', a secular theology about 'religionless Christianity', the 'costly grace' option for those for whom Christian commitment is best understood as an 'arcane discipline' which, in its intense action for the world, is shared with those of similar commitment across all faiths and no faith. Bonhoeffer's interfaith engagement (including faith with non-faith) is complete. Faith (and even no faith in some cases) entails radical action for others. It is in this recognition and his clear commitment to personalizing it and bringing it to effect that Bonhoeffer's credentials as practical mystic are realized.

\section{Practical Mystic}

Bonhoeffer is referred to in the literature as a mystic and certainly the depth of his prayer life and modeling the contemplative state places him in the company of those Christian saints to whom the tradition looks for guidance in matters of systems of prayer and meditation (Bonhoeffer, 1986; Frick, 2008; Lovat, 2012; Wiseman, 2006; Fox, 2011). At the same time, the title of 'mystic' is not used lightly or unadvisedly of Bonhoeffer, granted he does not fit the expected criteria of being austere and removed from life. On the contrary, Bonhoeffer's mysticism, if it is a fair claim, is characterized by its exceptional humanity and engagement with the realities of life, including an essential interfaith, and faith to non-faith, engagement. If a mystic at all, one might say Bonhoeffer was a pragmatic one, one who employed his mystical gifts to engage all the more readily with the challenges that beset him. In this context, it might be interesting to ponder on ancient tenets of mysticism, especially practical mysticism, to which I will claim Bonhoeffer conforms in both his interfaith engagement and his 'costly grace’ actions that so surpassed the human norm (Lovat, 2006a).

Abraham ben Samuel Abulafia, medieval Jewish mystic, is most associated with later Jewish Kabbalah and acknowledged to have had influence on, as well as been influenced by, both Christian and Islamic mysticisms (Idel, 1989). So central to his mystical beliefs was the interfaith engagement with his sibling Abrahamic religions that he came to postulate that the 
ultimate mystical experience could only be had by one who was saturated by all three Abrahamic spiritualities. He advocated that, in the name of the 'God of us all', all contestation between Judaism, Christianity and Islam should be dissolved in favour of accord and spiritual confluence between the three religions. For Abulafia, this ultimate mystical experience was centrally about practical action, a form of moral activity that was beyond the human norm and became itself both the effect and cause of mystical union with God. It is in the latter notion, namely of practical action as cause of the mystical experience that both the distinctiveness of Abulafia's contribution to mystical thought and the pertinence to Bonhoeffer is to be found.

In arguing against the common misapprehension that Kabbalah is essentially an austere and reclusive entity divorced from the practicalities of life, Idel (1988) makes use of Abulafia's imponderable notion of authentic mysticism as entailing an inherent circularity, namely, that the noblest forms of human behaviour play a role both as cause and effect of genuine mystical experience among followers of the Abrahamic faiths:

$\ldots$ in the profundities of human thought there is no one more profound and more excellent than it (= the product of mystical union) and it alone unites human thought with the divine (thought) to the extent of the human capability and according to human nature. And it is known that human thought is the cause of his wisdom, and his wisdom is the cause of his understanding, and his understanding is the cause of his mercy, and his mercy is the cause of his reverence of his Creator. (p. 147)

So, wisdom causes understanding which, in turn, causes mercy but, in a circular move, it is mercy that actually causes knowledge and submission to one’s God. For Abulafia, there can be no authentic claim to have achieved mystical union without the practical expression of doing the good, indeed of doing good that is beyond the human norm. Cordovero (1974), a seminal figure in the later medieval revival of Jewish mysticism, utilizes Abulafia's notion that authentic mysticism will always result in the potential for practical action that is beyond the human norm. The reason Cordovero offers is that there can ultimately be no true mystical experience without emulating God in his sephiroth, in a word, in his total immersion in and commitment to the practicalities of life. The true mystic must engage in practical action therefore which conforms to godly practice. The attributes of such practical action include complete identification with one's neighbour, 
mercy beyond the letter of the law, forgiveness to the point of eradicating the evil done and eliminating all traces of vengefulness and a range of actions of the highest moral order, quite beyond the scope of normal human virtue. For Cordovero, that was precisely the proof that allowed the genuine mystical experience to be identified and confirmed (cf. Epstein, 1988). The motivation to do the good was embedded in a profound sense of one's own integrity (in this case, in relationship with God) and the consequent requirement (desire) to act for the moral good. There can be no relationship or even claim of a relationship with God without the outpouring of mercy.

So, for Abulafia, the fruit of mysticism, as well as its impulsion, is in practical action of inordinately high moral goodness. Where mysticism might normally connote faith and knowing, Abulafia's 'practical mysticism' is about these conjoined with doing. It is a mystical knowing that implies and impels practical action for good. For Abulafia, this conception of mysticism came as the result of an interfaith engagement. Like Bonhoeffer, Abulafia came to know the Lord of the World (or at least the Lord of the Abrahamic religions) and, through that newfound knowledge, came to see a level of consistency between these religions that led him to enjoin them to cease their pretense about being different and to unify. Some of the consistency was to be found in language and the hermeneutics applied to their respective 'books' (cf. Halbertal, 1997) while much of it was to do with the elusive virtue that Abulafia saw at the heart of the mysticism of each of the Abrahamic religions and presumably their most significant heroes, Moses, Jesus and Muhammad. It is the mysticism of love (cf. Idel \& McGinn, 1999; Heyd, 1996; Dupre, 2007), the most authentic of those mysticisms judged to be genuinely religious in the Abrahamic traditions. Moses, Jesus and Muhammad, each of them subjects of the most unimaginably profound experiences of God, were at pains to stress the indispensable nature of their practical effects. In Exodus 32, Moses' frustration is with those who saw the outer expressions of religiousness as the goal of religion rather than the practical goals chartered in the Ten Commandments. In Luke 19, it is in Jesus' uncharacteristically harsh words against those who promoted the form of religion but lacked its force. And in Qur'an, 107, Muhammad's typical prophetic reaction to what he saw as the empty forms of the vestiges of the Abrahamic religions that he encountered was to design the Five Pillars as essential tenets of Islam that could never be reduced to mere form. For each of the Pillars, only an action would suffice, including the practical application of charity by means of the giving of alms to those in need. 
The notion of 'practical mysticism' in the Abrahamic religions of his day (Judaism and Christianity) is most associated with Plotinus (1964), the third century Egyptian scholar whose own pragmatism was seen in his teaching his students the difference between public and private spirituality and the necessity to cultivate both if they were to succeed in the world (Armstrong, 1996). Hence, he proposed a balance of spiritualities that could work for people in their day to day settings while also guaranteeing a constructive relationship with their god. Public spirituality was constituted of outer expressions of religiousness and for the benefit of the outer world. Private spirituality, on the other hand, concerned what passed between individuals and their god. While public spirituality had a role to play in social order and personal achievement, it was only through private spirituality that deeper religiousness, a higher consciousness about god and understanding the implications of the mystical relationship that ensued from such consciousness, could be achieved. Consistent with the notion of mysticism and love being at the heart of the Abrahamic religions, Idel and McGinn (1999) refer to this deeper religiousness as “... Plotinus’s ... favoring of love over understanding.” (p. 22) Plotinus names it as 'practical mysticism', the most authentic expression of private spirituality.

Underhill (1915) testifies that it is Plotinus's name that is most associated with the notion of practical mysticism, the counter-intuitive conception that mysticism is not best defined via the connotation of inactivity, retreat or disengagement, but rather through its opposite, namely active moral engagement: "The active man is a mystic when he knows his actions to be a part of a greater activity,” says Underhill (1915) in reference to Plotinus’s understanding. Underhill also proffers that "mysticism is the art of union with reality." The mystic, in other words, is not one who indulges in outward displays of religiousness, no matter how effusive and seemingly holy, but rather the one who, in Plotinus's terms, favors and effects love, practical action for good, as the essential outpouring derived from one's loving relationship with god:

Action always has some good or other in view - a good for oneself, to be possessed. Possessed where? In the soul. The circuit is complete: through action, the soul comes back to contemplation. (Plotinus, 1964, pp. 167-168)

Idel and McGinn (1999) endorse the view that, in terms of the nature of mysticism, there is more in common between the Abrahamic religions than separates them and that the common core is to be found around Plotinus' favouring of love over understanding, the 
most authentic religious expression for the Jewish, Christian and Islamic traditions, an authenticity that is replete with a sense of ethical mission:

The division of the mind postulated here enables the mystic to combine a contemplative life with one of active service. Yet by describing the two attitudes as juxtaposed, one risks missing their real nature. For one is not superimposed to the other: the two intimately collaborate and reinforce each other ... the mystical state, far from diminishing this unique ability to integrate, enhances the powers from a single dynamic source of concentration.

Generally speaking, for each of the three religions, the mystical union enhances a person's capacity to fulfil his or her given or assumed task ... All genuine mysticism results in spiritual fecundity. (pp. 13-14)

In a word, the combination of Bonhoeffer's personal spirituality and practical action constituting martyrdom would appear to qualify him being numbered among the Abrahamic practical mystics. Furthermore, as is at the heart of this article's intentions, it is through his interfaith, and faith to non-faith, engagement that he is brought to this form of practical action of such inordinately high moral order.

\section{Fusing Interfaith Engagement and Practical Mysticism}

As suggested throughout and as defined within, the notion of practical mysticism seems to capture the essence of Bonhoeffer's latter day faith journey, providing understanding of otherwise inexplicable language, theology, dispositions and actions. Bonhoeffer came to a form of mysticism, of 'costly grace' proportions, by having all the sureties of his earlier faith and theological attenuations challenged if not undermined. This conservative and assured Lutheran Christian was forced to re-evaluate the very foundations on which his faith had rested, coming to see the God who lay behind it as an object of religion rather than 'Lord of the World' for a 'World Come of Age'. While tempted perhaps to abandon this faith for faiths, or even non-faith, that he saw as more effectively responding to the needs of this world, he chose to stay within the bounds of his Lutheran Christianity, albeit through a Professing rather than Reich expression of it. Furthermore, in an ironic way, he chose to re-trace the steps of his inspirational saint, Luther, to find what was left of a Christianity brought to its knees through its compromise with forces of darkness. In this quest, he could look beyond the particularities of Luther's own blind spots to see the 
authentic Christian who would stand for the good regardless of the cost, as the most fundamental of Christian actions.

So, for Bonhoeffer, his interfaith engagement led him back to understanding his own faith in renewed fashion and especially coming to know the Lord of the World who sat behind it. It was this faith and this Lord who he saw impelling a 'religionless Christianity', a 'nonreligious interpretation' of the original Christian tradition for a 'World Come of Age'. In this Lord, Bonhoeffer found a God who is beyond all religious traditions and indeed beyond religiousness itself. This is the true Lord of the World who judges all by their actions rather than their affiliations. When those with no claims on this God are living out godly actions, there can be no authentic claim by those who do make claims on this Lord who do not also live by godly action. It is at this point that Bonhoeffer's credentials as practical mystic become evident. Bonhoeffer's renewed sense of and relationship with his Abrahamic God necessitated action in accord with that relationship. In his circumstances, this could only mean standing with Luther against the palpably wrong and corrupt and, in his case, especially by his fellow suffering beings, regardless of the cost. In this practical action, we see both the effect but also the cause of his mystical experience.

\section{Conclusion}

The article has attempted to argue for Bonhoeffer's credentials as a prime agent of interfaith engagement and hence offering at least the basic tenets and thrust of an interfaith theology for a religionless age, a World Come of Age. Furthermore, the article has attempted to show that this interfaith engagement, in conversation with his Lutheran Christian foundations, impelled the actions by which he is best known, namely taking a stand against an unjust regime and being martyred for it. It is in this latter action, combined with the nature of his personal spirituality, that we find his credentials as practical mystic.

\section{References}

Al-Daddak, K. (2012). Reconciling Traditional Islamic Methods with Liberal Feminism: Reflections from Tunisia by Mohamed Talbi. In T. Lovat, (Ed.), Women in Islam: Reflections on Historical and contemporary research. Dordrecht, Netherlands: Springer.

Alston, W. \& Welker, M. (Eds.), (2003). Reformed theology: Identity and ecumenicity. Grand Rapids, MN: Wm B. Eerdmans.

Armstrong, A. tr. (1996). Plotinus, Ennead II. Loeb Classical Library. Cambridge, MA: Harvard University Press. 
Barth, K. (1994). Church dogmatics. Louisville, Kentucky, USA: Westminster John Knox Press.

Bethge, E. (1970). Dietrich Bonhoeffer. London, UK: Collins.

Bonhoeffer, D. (1960). The cost of discipleship. (transl. R. Fuller) New York: Macmillan.

Bonhoeffer, D. (1986). Meditating on the Word. Nashville, Tennesee: Cowley Publications.

Bonhoeffer, D. (1998). Letters and papers from prison. London: SCM.

Chazan, R. (2004). Fashioning Jewish identity in medieval Western Christendom. Cambridge: Cambridge University Press.

Cordovero, M. (1974). The palm tree of Deborah. (tr. L. Jacobs) New York: Hermon Press.

Dupre, L. (2007). Mysticism among the world's religions. In. C. Meister \& P. Copan (Eds.), Routledge companion to philosophy of religion. (pp. 249-258) Oxford: Routledge.

Epstein, P. (1988). Kabbalah: The way of the Jewish mystic. Boston: Shambhala.

Fackenheim, E. (1977). Fackenheim on Bonhoeffer. Newsletter of the international Bonhoeffer society for archive and research (English Language Section), 11, 2-4.

Fackenheim, E. (1982). To mend the world: Foundations of post-Holocaust Jewish thought. New York: Schocken.

Fox, M. (2011). Christian mystics. Novato, CA: New World Library.

Frick, P. (Ed.), (2008). Bonhoeffer's intellectual formation: Theology and philosophy in his thought. Tubingen: Mohr Siebeck.

Goddard, H. (1995). Christians and Muslims: From double standards to mutual understanding. Richmond, UK: Curzon.

Haberman, J. (1994). The God I believe in: Conversations about Judaism. New York: Free Press.

Halbertal, M. (1997). People of the book: Canon, meaning, and authority. Cambridge, MASS: Harvard University Press.

Hamilton, J. (1962). A secular theology for a world come of age. Theology Today, 18(1), 435-459.

Heyd, D. (Ed.), (1996). Toleration: An elusive virtue. Princeton, NJ: Princeton University Press.

Hick, J. (1973). God and the Universe of Faiths. London, UK: Macmillan.

Hick, J. (1980). God has many names. London, UK: Macmillan. 
Hick, J. (1988). An interpretation of religion: Humanity's varied response to the transcendent. London, UK: Palgrave.

Hick, J. (1995). A Christian theology of religions: The rainbow of faiths. Louisville, Kentucky, USA: Westminster John Knox Press.

Hood, J. (1995). Aquinas and the Jews. Philadelphia, PA: University of Pennsylvania Press.

Idel, M. (1988). Kabbalah: New perspectives. New Haven, Conn: Yale University Press.

Idel, M. (1989). Language, Torah, and hermeneutics in Abraham Abulafiah. Albany, NY: State University of New York.

Idel, M. \& McGinn, B. (Eds.), (1999). Mystical union in Judaism, Christianity, and Islam: An ecumenical dialogue. New York: Continuum.

Jacobs, S. (2009). Confronting genocide: Judaism, Christianity, Islam. Lanham, MD: Lexington Books.

Lovat, T. (2006). The contribution of Hinduism and Hindu-inspired spirituality to Australian religious and values education. In M. de Souza, K. Engebretson, R. Jackson \& G. Durka (Eds.), International handbook of the religious, spiritual and moral dimensions in education. (pp. 487-499) Dordrecht, Netherlands: Kluwer.

Lovat, T. (2006a). Practical mysticism as authentic religiousness: A Bonhoeffer case study. Australian E-Journal of Theology, 6. Available at:

http://dlibrary.acu.edu.au/research/theology/ejournal/aejt_6/lovat.htm

Lovat, T. (2010). Interfaith theology for the twenty-first century: An artefact for faith in a global era. In J. Jaworski (Ed.), Advances in sociology research (Volume 7) (pp. 189-198). New York: Nova Science.

Lovat, T. (2012). Christian meditation: Window to Christianity’s soul. In K. Acharya (Ed.), Meditation in world religions. Mumbai: Somaiya Institute Press.

Marty, M. (2011). Prison writings in a world come of age: The special vision of Dietrich Bonhoeffer. Berfrois: Intellectual jousting in the Republic of Letters, May 20. Available at: http://www.berfrois.com/2011/05/martin-e-marty-on-bonhoeffer/

Metaxas, E. (2010). Bonhoeffer: Pastor, martyr, prophet, spy. Nashville: Thomas Nelson.

Michael, R. (2006). Holy hatred: Christianity, anti-Semitism and the Holocaust. New York: Palgrave.

Moses, J. (2009). The reluctant revolutionary: Dietrich Bonhoeffer's collision with PrussoGerman history. Oxford: Berghahn.

Pangritz, A. (1997). Sharing the destiny of his people. In J. de Gruychy (Ed.), Bonhoeffer for a new day: Theology in a time of transition (pp. 258-277). Grand Rapids, MN: Wm B. 
Eerdmans.

Pangritz, A. (1997a). 'Mystery and commandment' in Leo Baeck and Dietrich Bonhoeffer. European Judaism, 30(2), 44-57.

Plotinus (1964). The essential Plotinus. (transl. E. O’Brien) Indiana, Ind: Hackett Publishing co.

Pugh, J. (2008). Religionless Christianity: Dietrich Bonhoeffer in troubled times. (foreword by Martin E. Marty) London: T. \& T. Clark.

Rasmussen, L. (2005). Dietrich Bonhoeffer: Reality and resistance. Louisville, KY: Westminster John Knox Press.

Rumscheidt, M. (1991). Adolf Von Harnack: Liberal theology at its height. Minneapolis: First Fortress Press.

Talbi, M. (1995). Unavoidable dialogue in a pluralist world: A personal account. Encounters: Journal of Inter-cultural Perspectives, 1 (1): 56-69.

Talbi, M. (2002). Universalité du Coran. Arles, France: Actes Sud.

Talbi, M. \& Jarczyk, G. (2002). Penseur libre en islam. Paris, France: Albin Michel.

Underhill, E. (1915). Practical mysticism. New York: E.P. Dutton \& co. Available at: http://isom.vnsalvation.com/Resources\%20English/Christian\%20Ebooks/Evelyn\%20Underhi $\underline{11 \% 20 \text { Practical\%20Mysticism.pdf }}$

Wiseman, J. (2006). Spirituality and mysticism: A global view. New York: Orbis Books. Wustenberg, R. (1998). A theology of life: Dietrich Bonhoeffer's religionless Christianity. Grand Rapids, MN: Wm. B. Eeerdmans. 